\title{
RADICAL THACIPR
}

A SOCIALIST, FEMINIST, AND ANTI-RACIST JOURNAL ON THE THEORY AND PRACTICE OF TEACHING

\section{Contributors' Notes}

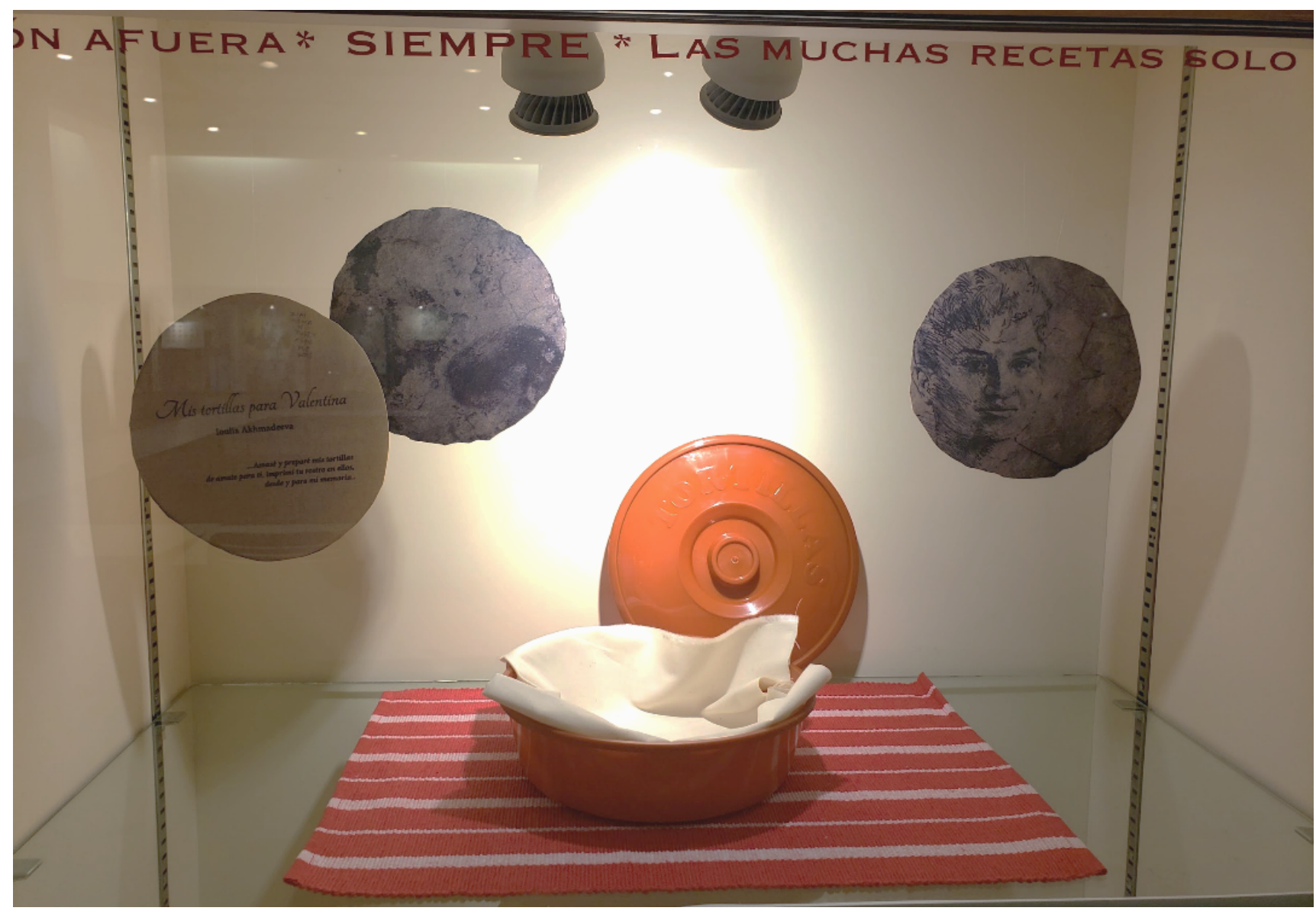

IMAGE COURTESY OF STEPHANIE J. BEENE, LAURI M. GONZÁLEZ AND SUZANNE M. SCHADL, FROM THE EXIBITION "TOMES" (2018). THE UNIVERSITY OF NEW MEXICO 
Abena Ampofoa Asare is Assistant Professor of Africana Studies and History at Stony Brook University. She is the author of Truth Without Reconciliation: A Human Rights History of Ghana (University of Pennsylvania Press, 2018).

Stephanie J. Beene is Assistant Professor and Fine Arts Librarian for Art and Architecture at the Fine Arts and Design Library, within the College of University Libraries \& Learning Sciences at the University of New Mexico.

Michael Bennett is Professor Emeritus of English, Long Island University (Brooklyn). He has published on American literature, African American studies, and urban culture \& ecology. His latest work has been creative. He is on the editorial board of Radical Teacher.

Erica Cardwell is a culture critic and educator in New York. She teaches English and Lit at the Borough of Manhattan Community College and movement building and social justice at The New School. Her most recent writing was featured for The Believer and Green Mountains Review. She lives in Brooklyn with her wife Zhaleh and their turtle, Smiley Mousa.

Sarah Chinn teaches in and is chair of the English department at Hunter College, CUNY. She has published widely on a variety of issues from transgender Title VII cases to food justice to the U.S./Mexico war. Her most recent book is Spectacular Men: Race, Gender, and Nation on the Early American Stage (2017).

Peter Neil Carroll has published five collections of poetry, including An Elegy for Lovers(Main Street Rag) and The Truth Lies on Earth: A Year by Dark, by Bright (Turning Point). Previous titles include Fracking Dakota: Poems for a Wounded Land; Riverborne: A Mississippi Requiem; and A Child Turns Back to Wave: Poetry of Lost Places, which won the Prize Americana. He is currently Poetry Moderator of Portside.org.

Andrea Dupre holds MA degrees in English Literature and Secondary Education from Binghamton University and taught for many years in upstate New York and New York City. Her next project will explore the state of the teaching profession in America.

Abby Emerson is a $5^{\text {th }}$ Grade public school educator in New York City. She is interested in culturally-sustaining pedagogies, anti-racist practices, and the development of racial literacies in people that work with children.
Frank Farmer is Professor Emeritus of English at the University of Kansas. He is the author of After the Public Turn: Composition, Counterpublics, and the Citizen Bricoleur (UP of Colorado, 2013) and Saying and Silence: Listening to Composition with Bakhtin (Utah State UP, 2001). He is also the editor of Landmark Essays on Bakhtin, Rhetoric, and Writing (Routledge, 1998), and his work has appeared in journals as various as JAC, Rhetoric Society Quarterly, symploke, Common Knowledge, Russian Review, Written Communication, and College English. He retired this past summer after an academic career that spanned four decades.

Lauri M. González is a recent graduate of the MA program in Latin American Studies with concentrations in both Indigenous Studies and Urbanism \& Community Development at the University of New Mexico. She received the Deborah and John Yeakel Endowed Fellowship and four Foreign Language \& Area Studies (FLAS) Fellowships to study K'iche' Maya and Quechua. She is currently doing research in Puebla, Mexico.

Jessi Lee Jackson is a mental health clinician in practice in Vancouver, BC. She has a PhD in American Studies (SUNY-Buffalo) and an MA in Counseling Psychology (Northwestern).

Lawrence Johnson is an Assistant Professor in the department of sociology at Brooklyn College. His areas of research includes racism, politics, and sports.

MEH is Matthew E. Henry, a Pushcart nominated poet with works appearing or upcoming in various publications including 3Elements Review, The Anglican Theological Review, Kweli Journal, Poetry East, Rhino, and Spillway. $\mathrm{MEH}$ is a high school teacher who received his MFA from Seattle Pacific University, yet continued to spend money he didn't have pursuing a MA in theology and a PhD in education. Currently, he's channeling his militant, angryBlack-man-ness through his poetry.

Suzanne M. Schadl is currently an Associate Professor and curator of Latin American collections at the University of New Mexico. Schadl will join the Library of Congress in Washington, D.C. as the Chief of the Hispanic Division in October 2018. (cc) EY-NG-ND

ULLS D-Sante
This work is licensed under a Creative Commons Attribution-Noncommercial-No Derivative Works 3.0 United States License.

This journal is published by the University Library System of the University of Pittsburgh as part of its D-Scribe Digital Publishing Program, and is cosponsored by the University of Pittsburgh Press. 